\title{
Examination of Gel Hand Sanitizer from Mangrove Leaves and Patchouli Oil Against Sthapylococcus Aureus
}

\author{
Fahreni $^{1}$, Vivi Mardina ${ }^{1 *}$, Indriaty ${ }^{2}$, Ramaidani $^{1}$ \\ ${ }^{1}$ Department of Biology, Faculty of Engineering, Universitas Samudra, Aceh, Indonesia \\ ${ }^{2}$ Department of Biology Education, Faculty of Teacher Training and Education, Universitas Samudra, Aceh, Indonesia \\ *Corresponding author E-mail: vmardina@unsam.ac.id
}

Manuscript received 15 August 2021; revised 1 Sept 2021; accepted 15 Sept 2021. Date of publication 4 Nov 2021

\begin{abstract}
The development of hand sanitizers from a combination of mangrove leaves and patchouli oil has not yet developed in the world and Indonesia, though these two natural ingredients have antibacterial activity as a substitute for alcohol. It is known that many alcohol-based hand sanitizers can cause burning, irritation, dry skin, and cannot be used on wound skin. The purpose of this study was to develop an innovative hand sanitizer in the form of a gel from a combination of mangrove leaves extract and patchouli oil from Aceh. The samples of mangroves (Avicennia) leaves and Patchouli oil were collected from the Kuala Langsa Mangrove Forest and patchouli farmers in South Aceh. Staphylococcous aereus bacteria were obtained from the Laboratory of Universitas Sumatera Utara. This study used a completely randomized design (CRD) with three replications for the gel formulation. The study prepared four formulations namely $\mathrm{K}(-)$ as control without mangrove extract and patchouli oil, F-I contained $1 \mathrm{~g}$ mangrove extract and 10mL patchouli oil, F-II contained 5g mangrove extract and $20 \mathrm{~mL}$ patchouli oil, and F-III contained $10 \mathrm{~g}$ mangrove extract and $30 \mathrm{~mL}$ patchouli oil. Gel hand sanitizer formulations were test for antibacterial active using diffusion method against $S$. aereus. The data were analyzed using one-way ANOVA. The results of the gel hand sanitizer formulation showed inhibitory effect against $S$. aereus with the diameter zones of $12.6 \mathrm{~mm}, 21.33 \mathrm{~mm}$, $19.61 \mathrm{~mm}$ and $25 \mathrm{~mm}$ for negative control, F-I, F-II, and F-III. The F-III formulation was found as the maximum formula to inhibit the growth of $S$. aereus.
\end{abstract}

Keywords: Hand Sanitizer, Mangrove, Patchouli Oil, Antibacterial Activity.

\section{Introduction}

At the January of 2020, this planet was shocked by an outbreak of the novel corona virus or known as Covid-19 which is pandemic. WHO declared the world entered a situation global emergency-related Covid-19 since March 11 ${ }^{\text {th }}$, 2020 [1]. This is a fenoumena extraordinary happened on Earth in the 21st century, that the scale may be likened to the World War II, due to large-scale events such as international sporting events are almost entirely be delayed and even canceled. This condition has occurred only during the world war, there has never been another situation that can cancel these events. As of March 19, 2020, 214.894 people were infected with the corona virus, 8.732 people died and 83.313 people have recovered [2]. Particularly in Indonesia, since March 2, 2020 the Government has been reported there are 2 cases og Covid-19 and on April 2, 2020, this country extended 1790 confirmed cases with 170 total of death and 112 tota; of recoveries. The government has been taken the policies to resolve this extraordinary case such as Social Distancing that each human must maintain a safe distance from others at least 2 meters and avoid mass gatherings or not contact directly to others [3]. In addition, hand washing well with soap or hand sanitizer highly recommended [4] [5].

Handsanitizer is an antiseptic material that can kill microorganisms in a relatively short time [4]. Use of handsanitizer shown to effectively lower the respiratory and gastrointestinal infections caused by bacteria such as Staphylococcous aereus, Escherichia coli and Vibrio cholerae [6]. Practical use of hand sanitizers up to the recommended right to health workers and the public. This may be because the compounds contained in hand sanitizers have a mechanism of action by denaturing and coagulating germ cell proteins[7] [8].

There are hand sanitizer products in liquid and gel forms [7]. Gel hand sanitizer is more popular with the public because cool in the skin, high bonding strength that does not clog pores, good spreadability on the skin, dries easily and easily washable with water. The main ingredient of hand sanitizer is alcohols (ethanol, propanol, isopropanol) that have concentration of 50\% till 70\% [9]. However, use alcohol continuously can cause dryness and irritation by eroding the surface of the skin, dissolving the layer of fat and sebum of the skin. In addition, alcohol also has flammable properties [10] [11]. Therefore, innovation of natural ingredients for hand sanitizer that is safer to the skin is required. One of them is combination of mangrove leaves (Rhizosporaapiculata) and patchouli oil (Pogostemo ncablin benth) which have properties antimicrobes. 
Rhizopora Avicennia is mangrove species that was used as a traditional medicine to cure illnesses skin, rheumatism, measles, boils, and animal feed ingredients [12]. Moreover, mangrove Avicennia is a source of alcohol, amino acids, carbohydrates, fatty acids, hydrocarbons, minerals, phytoalexin, carboxylic acids, vitamins and glucoside [13]. Besides mangroves, Aceh is rich in patchouli plants, Pogostemin cablin Bench, which contains patchouli alcohol from patchouli oil [14] [11]. Patchouli alcohol is used as a fixative (binding agent) in the perfume industry and a component of cosmetic products. Patchouli oil was utilized for antifungal, insect, antiimflamasi, and antiflogistik [15]. The hand sanitizers that consist of mangrove exstract and patchouli oil are not developed yet in the world and Indonesia; though both of these natural ingredients have antibacterial antivities and can be used to substitute for alcohol ingredient. It is known that many alcohol-based hand sanitizers can cause burning, irritation, dry skin, and cannot be used on wound skin. Thus, this study is an effort to develop the innovation of hand sanitizers that consists of mangrove exstract and patchouli oil

\section{Method}

The study was conducted from July to December 2020. The mangroves (Avicennia) leaves was collected from the Kuala Langsa Mangrove Forest, Aceh. Patchouli oil samples were collected from patchouli farmers in South Aceh. Staphylococcus aureus bacteria were obtained from the Laboratory of the Universitas Sumatera Utara. This study used a completely randomized design (CRD) againts S. aureus. Each antibacterial test of the gel preparation was repeated three times. The antibacterial gel formula (hand sanitizer) is shown in table 1 . The observation parameter was the inhibition zone (clear zone) around the wells that were not overgrown with other bacteria. Data were analyzed by using one-way ANOVA to know the differences among formulas.

Table 1. Hand sanitizer gel formula from mangrove leaves extract and patchouli oil

\begin{tabular}{llcccc}
\hline Material & Unit & Control (K (-)) & F - I & F - II & F - III \\
\hline Mangrove leaf extract (antimicrobial potential) & $\mathrm{G}$ & - & 1 & 5 & 10 \\
\hline Patchouli oil (antimicrobial potential) & $\mathrm{mL}$ & - & 10 & 20 & 30 \\
\hline Alcohol (solvent) & $\mathrm{mL}$ & 50 & 39 & 25 & 10 \\
\hline Triclosan & $\mathrm{G}$ & 0.2 & 0.2 & 0.2 & 0.2 \\
\hline Carbopol (rheology modifier, solubility) & $\mathrm{G}$ & 0,50 & 0,50 & 0,50 & 0,50 \\
\hline Glycerin (moisturizer) & $\mathrm{mL}$ & 2.00 & 2.00 & 2.00 & 2.00 \\
\hline Triethanolamine (neutralizer) & $\mathrm{mL}$ & 0.80 & 0.80 & 0.80 & 0.80 \\
\hline Methyl Paraben (preservative) & $\mathrm{G}$ & 0.10 & 0.10 & 0.10 & 0.10 \\
\hline Aquades up to (diluent) & $\mathrm{mL}$ & 46,40 & 46,40 & 46,40 & 46,40 \\
\hline
\end{tabular}

\subsection{Preparation of the Avicennia sp extract}

$5 \mathrm{~kg}$ of $R$. Apiculata leaves were dried for $\pm 7-10$ days, cut into small pieces $( \pm 0.3 \mathrm{~cm})$. The samples were then extracted by maceration using methanol as a solvent. The maceration process was carried out for $3 \times 24$ hours 3 times and the maserated solution was filtered using Whatman filter paper No. 1, then evaporated to obtain the viscous extract [16], [17].

\subsection{Preparation of hand sanitizer gel}

In order to mix the ingredients into formula gel, firstly carbopol was put into water, stirred until dissolved, then triethanolamine (TEA) was added to develop carbopol. In a separate container, methyl paraben was dissolved in distilled water which has been heated until dissolved then put into carbopol which has been developed patchouli oil and mangrove leaves dissolved with glycerin, then put into the previous mixture at a temperature of $30{ }^{\circ} \mathrm{C}$. Stir until a thick gel mass was formed, clear and homogeneous, put in a suitable container and tightly closed [18].

\subsection{Test preparation of hand sanitizer gel against Staphylococcus aureus}

Preparation of bacterial suspension (inoculum) was carried out using method suggested by Mardina et al. [19]-[21]. One colony of Staphylococcus aureus was cultured in Nutrient Broth (NB ) media and incubated for $24 \mathrm{~h}$. The gel formulations were examined by the diffusion method to determine the inhibitory effect [22]. The formulation had the concentration of $2 \%, 4 \%$ and $8 \%$ (g/mL). Negative control was the gel formulation without mangrove extract and patchouli oil.

\section{Results and Discussion}

\subsection{Testing the Anti-Bacterial Activity of Hand Sanitizer Gel against Stapylococcus aureus}

The antibacterial activities of gel formulation against S.aureus were shown in Fig.4.1. and 4.2. Based on the graph in Figure 4.1.Formula III perfomed hand sanitizer gel showed the highest inhibition zone against Pertu m harbor $S$. aureus with a mean diameter of the resulting inhibition zone approaching $25 \mathrm{~mm}$, followed by formula I and II with the ma s ing the resulting inhibition zone maisng are $21.33 \mathrm{~mm}$ and $19.67 \mathrm{~mm}$. The negative control, which was gel preparation without additional patchouli oil and mangrove leaf extract, showed the lowest mean diameter of the inhibition zone was $12.6 \mathrm{~mm}$. The clear zone visualization of the hand sanitizer gel preparation is shown in Figure 4.2. Duncan test results stating that the negative control (without addition of gel formulation mi $\mathrm{n}$ yak patchouli and mangrove extract) significantly different from all sediannya gel / formula.Namun formula I do not significantly different with very different formula II and (significantly) in formula III.

Based on the graph in Figure 4.1 and the visualization of the inhibition zone (Figure 4.2), formula III is the maximum concentration that inhibits the growth of $S$. aereus bacteria. The results above recommended validation of the dosage of the gel preparation (maximum gel formula) by comparing (a) only patchouli oil and mangrove extract and (b) formula III. 


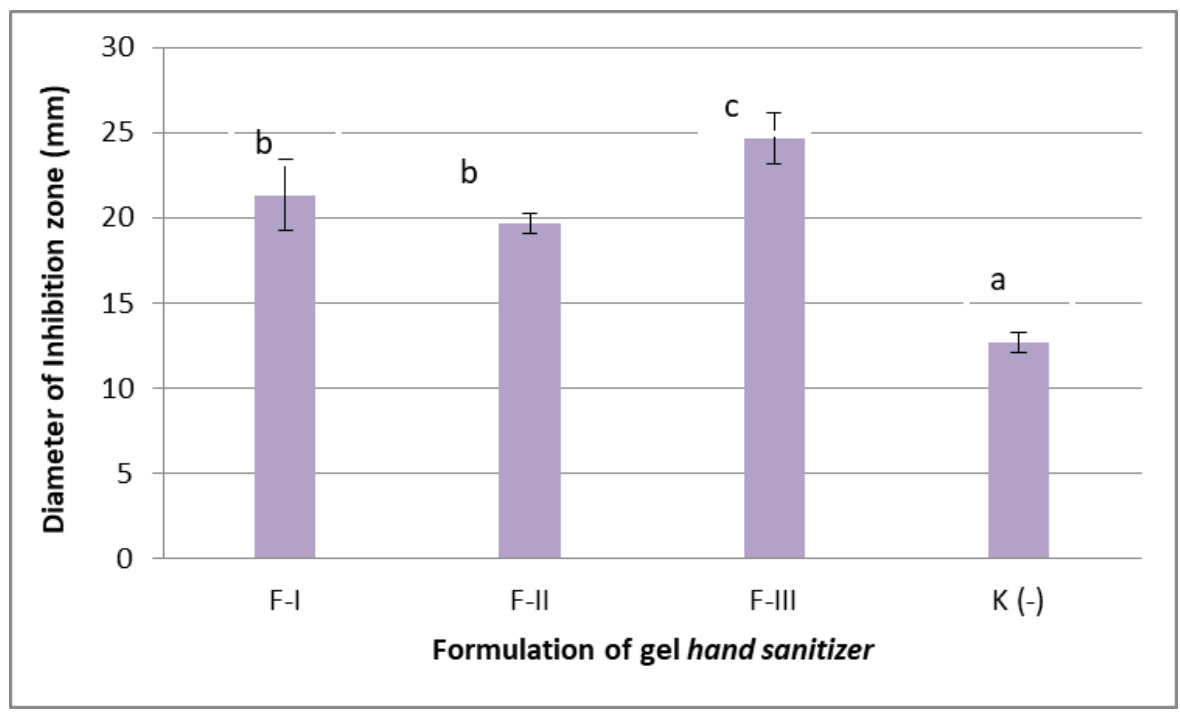

Fig 1. The diameter of the inhibition zone produced by the hand sanitizer gel against $S$. aureus bacteria. Note: Histograms followed by different letters show that there are significant differences between treatments.

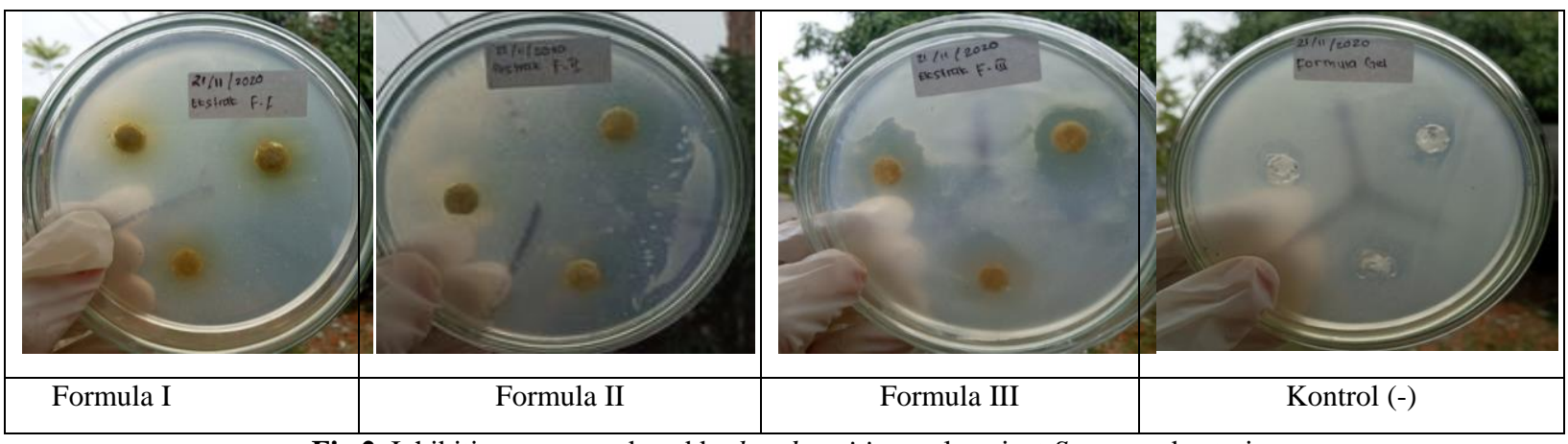

Fig 2. Inhibition zone produced by hand sanitizer gel against $S$. aureus bacteria .

In general antibacterial activities of the gel hand sanitizer against Stapyloccocus aureus showed the clear zone formation/ inhibition zone on each treatment. The control is without the addition of patchouli oil and mangrove leaf extract, the average of inhibition zone of the control has a diameter of $12 \mathrm{~mm}$. The formula I formed an average inhibition zone of $23 \mathrm{~mm}$. Formula II produced $19 \mathrm{~mm}$ of inhibition zone and in formula III produced $26 \mathrm{~mm}$ of inhibition zone. According, antibacterial activity is classified as having weak antibacterial activity if it has an inhibition zone with a value range of $6-10 \mathrm{~mm}$ and is categorized as active if it has an inhibition zone with a value range of 21-30 mm. The antibacterial activity of FI, F-II and F-III was strongly suspected due to the influence of secondary metabolites on patchouli oil and mangrove leaves. Pogostenom cablin Benth) which contains pathouli alcohol (PA) as the main component has antibacterial activity [23], [24]. Reported that the high levels of patchouli oil affected the diameter of inhibition zone particularly for gram-positive bacteria (Propionibakterium acnes, Stapylococcus aureus, stapylococcus epidermidis, and Micrococcus luteus) . The higher the patchouli oil content will result the higher diameter of inhibition zone against gram-positive bacteria. The antibacterial activity of patchouli oil was reported by Yang et al [25] because of the patchouli oil contain alkoloid, saponins, phenols, flavonoids, triterpenoids and glycosides which can inhibit the growth or kill bacteria of S. aureus and P. aeruginosa . Fauzi and Lely [23] extracted the essential oils from the leaves and stems of patchouli (Pogostemon cablin Benth) using steam distillation method. Characterization compounds and antimicroba assay activity were carried out using GC-MS and diffusion methods. The essential oils of patchouli leaves and stems contained patchouli alcohol (48.06\%), guaiene (18.24\%), guaiene (13.14\%), patchoulene (6.49\%), seychellene $(5,85 \%)$, caryophyllene $(3.01 \%)$, azulene $(2.66 \%)$, patchoulene $(1.24 \%)$, elemente $(0.96 \%)$, and humulene $(0.34 \%)$. Moreover, antimicrobial activity test was conducted with 5 concentration level of $10 \%, 20 \%, 30 \%, 40 \%$ and $50 \%(\mathrm{~g} / \mathrm{mL})$ against Streptococcus mutans ATCC 31 987, Pseudomonas aeruginosa ATCC 9027 and Candida albicans ATCC 01231. The results exhibited the leaves and stems of patchouli were able to inhibit the growth of P. aeruginosa at a concentrations of $50 \%$ (19.1 mm), while for S. mutans and C.albicans did not show the anti-microbial activity. Similarly, patchouli oil and mangrove leaves extracts have antibacterial activities [26]-[28]. Their results strongly supported that the presence of secondary metabolites in mangrove leaves inhibited the bacteria growth. Mulyani et al. [26]. reported that extracts of several types of mangroves (not mentioning the species) were identified containing flavonoids and saponins. Dewi et al [27]. reported that Mangrove Avicennia marina had been tested for its antibacterial activity against Vibrio sp at concentrations of $15 \%, 25 \%$ and $35 \%$. The results of the research reported that $35 \%$ of mangrove leaf extracts of A. marina as the maximum concentration against Vibrio spp with the zone inhibition of $30.75 \mathrm{~mm}$. Ciptaningrum and Daughter [28] reported that extracts of leaves, bark and roots of Rhizophora apiculata was able to inhibit the growth of P. aeruginosa, S. aureus, Streptococcus sp, and E. coli . Danata and Yamindago [29] reported that Avicennia marina was able to inhibit the growth of S. aureus and V. alginolyticus with the results of 4.43 to $5.79 \mathrm{~mm}$ and 4.25 to $5.48 \mathrm{~mm}$ respectively. The phytochemical test of his research identified the presence of secondary metabolites in A. marina, namely alkaloids, flavonoids, and saponins. Alhaddad et al [30] also reported the presence of antibacterial activity in Avicennia sp mangroves against S. aureus and E. coli. The results showed that the ethyl acetate extract of Avicennia sp leaves produced an inhibition zone of $16.97 \mathrm{~mm}$ against S.aureus and $14.40 \mathrm{~mm}$ against E.coli. The 
ethanol extract of Avicennia sp leaves produced an inhibition zone of $12.20 \mathrm{~mm}$ against $\mathrm{S}$. aureus and 8.13 mm against E.coli bacteria . The results of phytochemical analysis showed the presence of steroid compounds, triterpenoids, flavonoids, alkaloids and polyphenols.

\subsection{Dosage Validation on Gel Activity Test against $S$. aureus}

Validation dose was performed by testing the anti-bacterial activity of (i) the formula III (F-III), and (ii) 2x concentration of F-III, (iii) the positive control $\mathrm{K}(+)$ (only combination the patchouli oil and mangrove leaves extract without other gradients and (iv ) $2 x$ the positive control $[2 \mathrm{x}(\mathrm{K}+)]$. The test results were shown in Figure 3 and 4.

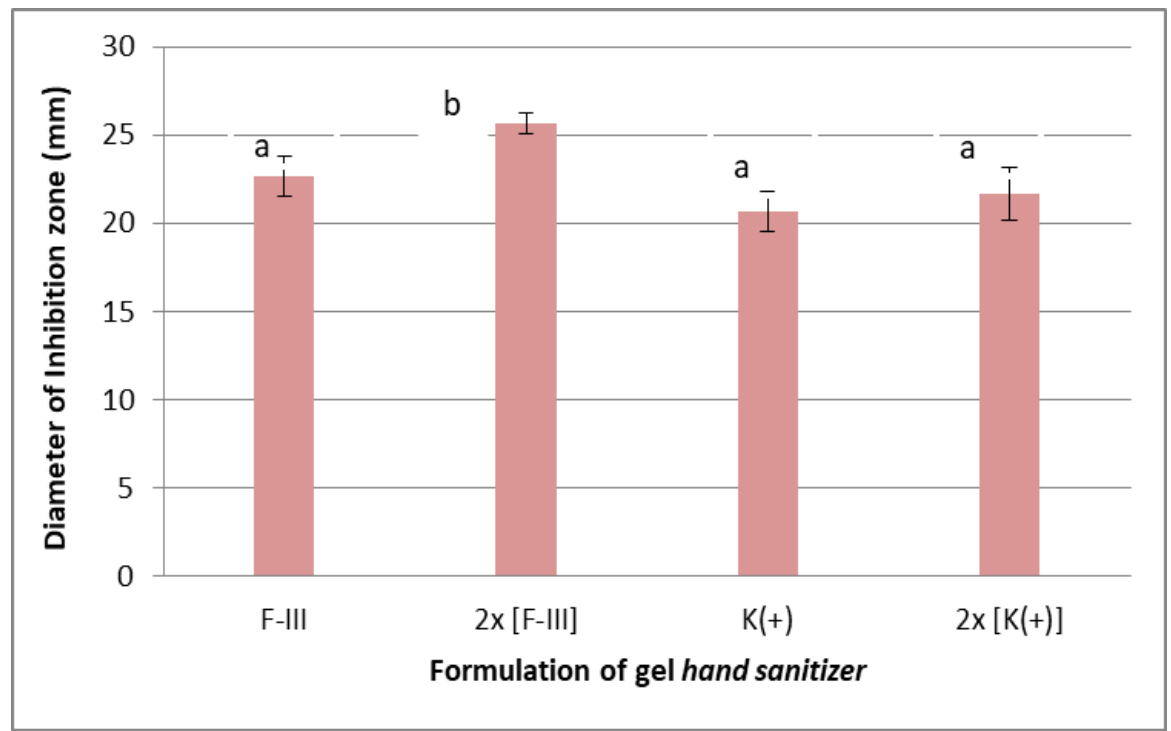

Fig 3. The average diameter of the inhibition zone in the validation test of the dosage of hand sanitizer gel preparations against $S$. aureus bacteria.

Note: Histograms followed by different letters show that there are significant differences between treatments

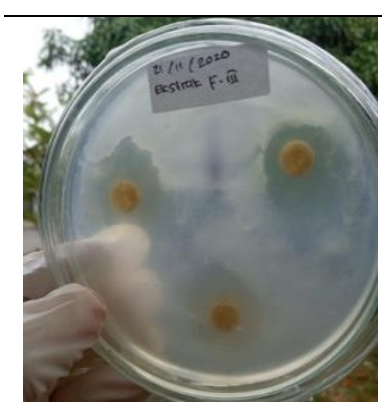

F-III

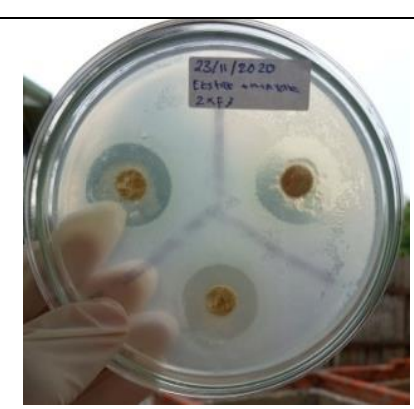

$2 \mathrm{x}[\mathrm{F}-\mathrm{III}]$

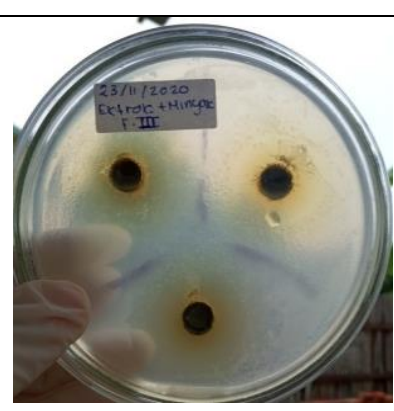

$\mathrm{K}(+)$

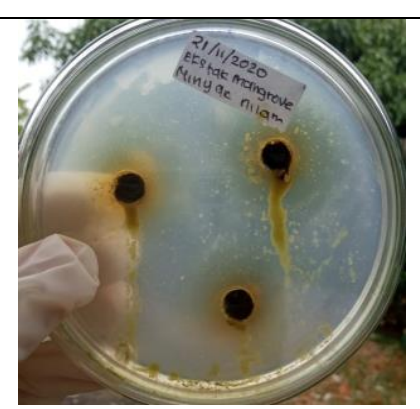

$2 \times[K(+)]$

Fig 4. Validation of formula III against $S$. aureus bacteria .

Based on Figures 3 and 4, F-III produces an average inhibition zone diameter of $22.67 \mathrm{~mm}$. The F-III test with two times concentration resulted an inhibition zone of $25.67 \mathrm{~mm}$. Positive controls were only patchouli oil and mangrove extract (with a concentration of $30 \mathrm{v} / \mathrm{v}$ and $10 \mathrm{w} / \mathrm{v}$ ) that resulted the inhibition zone under F-III formulation, thus it can be concluded that the inhibition zones in this study were produced from the gel hand sanitizer formulation (F-III).

The mechanism of secondary metabolites for an antimicrobial activity has been reported by Ciptaningrum and Putri [28]. Flavonoids have three actions as an antibacterial compound by inhibiting the synthesis of nucleic acids, membrane cells and energy metabolism. The flavonoids also may prevent the proliferation (cell division) bacteria with forming the complex compounds extracellular proteins which would interfere with the integrity of cell membranes. The action of Tannin by forming hydrophobic complexes with proteins, enzymes and cell wall transport proteins, thereby interfering with bacterial growth. Additionally, tannins can shrink cell walls or cell membranes thus they interfere with the permeability of these cells, cells cannot carry out living activities, inhibit growth or even die. Meanwhile, saponins work by lowering the cell surface tension, resulting in cell leakage (leaking cytoplasm) and resulting in cell death (lysis of bacterial cells) [22]. Widowati et al [25] describes the alkaloid compounds can inhibit the action of the enzyme on the bacterial protein synthesis by disruption the bacterial metabolism. Alkaloids also damage the constituent components of peptidoglycan in bacterial cells, so that the cell wall layer is not fully formed and causes bacteria to die. The phenolic content works as an anti-bacterial by denaturing cell proteins. The hydrogen bonds formed between phenol and protein cause the protein structure to be damaged. The hydrogen bonds will affect the permeability of the cell wall and the disturbed cytoplasmic membrane can cause an imbalance of macromolecules and ions in the cell so that it becomes lysis. The mechanism of action of triterpenoid compounds as antibacterial substances involve membrane damage by lipophilic compounds. Triterpenoids can react with porins (transmembrane proteins) on the outer membrane of the bacterial cell wall, forming strong polymer bonds and damaging the porin, reducing the permeability of the bacterial cell wall. As a results the bacterial cell lacks nutrients, and inhibits bacterial growth or dies. 


\section{Conclusion}

Research had tested the potential of patchouli oil and mangrove leaves as candidates for antibacterial hand sanitizer. The diameter largest inhibitory zone obtained in the formula III was $25 \mathrm{~mm}$ with patchouli and mangrove concentration of $30 \mathrm{v} / \mathrm{v}$ and $10 \mathrm{w} / \mathrm{v}$. Patchouli and mangrove extract were mixed with other ingredients hand sanitizer gel namely alcohol, triclosan, carbopol, glycerin, trietanolamin , methyl paraben and distilled water.

\section{References}

[1] F. Di Gennaro et al., "Coronavirus diseases (COVID-19) current status and future perspectives: A narrative review," Int. J. Environ. Res. Public Health, vol. 17, no. 8, pp. 2-11, 2020, doi: 10.3390/ijerph17082690.

[2] CNN, "Know social distancing as a way to prevent corona," 2020.

[3] R. Djalante et al., "Review and analysis of current responses to COVID-19 in Indonesia: period of January to March 2020," Prog. Disaster Sci., vol. 6, pp. 1-9, 2020, doi: 10.1016/j.pdisas.2020.100091.

[4] K. Abuga and N. Nyamweya, "Alcohol-based hand sanitizers in COVID-19 prevention: a multidimensional perspective," Pharmacy, vol. 9, no. 1, p. 64, 2021, doi: 10.3390/pharmacy9010064.

[5] S. Romadhona, F. Kurniawan, and J. Tistogondo, "Project Scheduling Analysis Using the Precedence Diagram Method (PDM) Case Study: Surabaya's City Outer East Ring Road Construction Project (Segment 1),” Int. J. Eng. Sci. Inf. Technol., vol. 1, no. 2, 2021, doi: 10.52088/ijesty.v1i2.56.

[6] D. P. Astuti, P. Husni, and K. Hartono, "Formulation and Physical Stability Test of Hand Antiseptic Gel Preparation Lavender Flower Essential Oil (Lavandula angustifolia Miller). Formulasi Dan Uji Stabilitas Fisik Sediaan Gel Antiseptik Tangan Minyak Atsiri Bunga Lavender (Lavandula angustifolia,” Farmaka, vol. 15, no. 1, pp. 176-184, 2017.

[7] A. P. Golin, D. C. Bhsc, and A. Ghahary, "Hand sanitizers: A review of ingredients, mechanisms of action, modes of delivery, and efficacy against corona viruses," Am. J. Infect. Control, vol. 48, no. 9, pp. 1062-1067, 2020, doi: 10.1016/j.ajic.2020.06.182.

[8] D. Kumar, "Power System Restoration Using Multilayer Perceptron," Int. J. Eng. Sci. Inf. Technol., vol. 1, no. 1, 2021, doi: 10.52088/ijesty.v1i1.35.

[9] A. S. Milala, M. Sofyan, and M. Wahjudi, "The formulation and antibacterial activity of hand sanitizer gels containing Lampes (Ocimum sanctum L.) Leaves Extract as An Active Compound,” Inatradmed. pp. 1--7, 2014.

[10] A. Mahmood et al., "COVID-19 and frequent use of hand sanitizers; human health and environmental hazards by exposure pathways," Sci. Total Environ., vol. 742, no. 140561, pp. 1-7, 2020, doi: 10.1016/j.scitotenv.2020.140561.

[11] M. Mahfut, "Identification and Efforts to Control Infection Odontoglossum ringspot virus (ORSV) on Orchid," Int. J. Eng. Sci. Inf. Technol., vol. 1, no. 1, 2021, doi: 10.52088/ijesty.v1i1.38.

[12] G. Saptiani, A. N. Asikin, F. Ardhani, and E. H. Hardi, "The potential of Avicennia marina to inhibits pathogen microbes and protects the post larva of tiger prawn. Tanaman bakau Api-api Putih (Avicenia marina) berpotensi menghambat mikrob patogen dan melindungi post larva udang windu.," Vet. J., vol. 19, no. 1, pp. 45-54, 2018, doi: 10.19087/jveteriner.2018.19.1.45.

[13] M. Ananthavalli and S. Karpagam, "Antibacterial activity and phytochemical content of Avicennia marina collected from polluted and unpolluted site," J. Med. Plants Stud., vol. 5, no. 3, pp. 47-49, 2017.

[14] H. Zuliansyah, B. Susilo, and S. HS, "Distillation plant performance test of patchouli (Pogostemon cablin , Benth) using boiler in Blitar. Uji performa penyulingan tanaman nilam (Pogostemon cablin, Benth) mengunakan boiler di Kabupaten Blitar.," J. Trop. Commod. Bioprocesses, vol. 1, no. 1, pp. 62-72, 2013.

[15] E. Sufriadi, Y. Aisyah, F. Harahap, Y. Fernando, and V. Mardina, "A method for aseptic culture of bud explants pogestemon cablin benth Var Tapak Tuan, Aceh, Indonesia,” IOP Conf. Ser. Mater. Sci. Eng., vol. 725, no. 1, pp. 1-5, 2020, doi: 10.1088/1757-899X/725/1/012066.

[16] V. Mardina, S. Ilyas, T. Harmawan, H. Halimatussakdiah, and M. Tanjung, "Antioxidant and cytotoxic activities of the ethyl acetate extract of Sphagneticola trilobata (L.) J.F. Pruski on MCF-7 breast cancer cell.pdf," J. Adv. Pharm. Technol. Res. Abstr., vol. 11, no. 3, pp. 123-127, 2020, doi: 10.4103/japtr.JAPTR_31_20.

[17] V. Mardina et al., "Preliminary phytochemical screening of different solvent extracts of flower and whole plant of Wedelia biflora," in IOP Conference Series: Materials Science and Engineering, 2020, vol. 725, no. 1, doi: 10.1088/1757-899X/725/1/012077.

[18] M. Shu, "Hand sanitizer gel formulation with $0.5 \%$ and $1 \%$ triclosan as the active ingredient. Formulasi sediaan gel hand sanitizer dengan bahan aktif triklosan 0,5\% dan 1\%.," Univ. Surabaya Student Sci. J., vol. 2, no. 1, pp. 1-14, 2013.

[19] V. Mardina and F. Yusof, "Skim Latex Serum as an Alternative Nutrition for Microbial Growth," in Multifaceted Protocol in Biotechnology, Springer Singapore, 2018, pp. 179-196.

[20] V. Mardina, F. Yusof, and M. Z. Alam, "Statistical optimization of physicochemical factors for protease production by bacillus licheniformis on skim latex serum fortified media," J. Eng. Sci. Technol., vol. 10, no. Spec.issue6, pp. 42$52,2015$.

[21] V. Mardina, F. Yusof, and M. Z. Alam, "Kinetic and Thermodynamic Characterization of the Protease from Bacillus licheniformis (ATCC 12759)," Elkawnie, vol. 6, no. 2, p. 178, 2020, doi: 10.22373/ekw.v6i2.7530.

[22] F. Helmalia, V. Mardina, Fadhliani, and Lendawati, "Anti-bacterial activity test of Baccaurea macrocarpa leaf methanol extract against Escherichia coli and salmonella typhi. Uji aktivitas anti bakteri ekstrak metanol daun 
Baccaurea macrocarpa terhadap Escherichia coli dan Salmonella typhi,” Bioconservation, vol. 17, no. 1, pp. 10-16, 2021.

[23] M. Fauzi and N. Lely, "Characterization and antimicrobial activity test of patchouli (Pogostemoncablin Benth) leaf and stem essential oil," Pharm. Serv. Sci. J., vol. 2, pp. 41-48, 2017.

[24] M. Dzakwan and U. Budi, "Antibacterial activity test of patchouli leaf essential oil ( Pogostemon cablin , Benth) against Staphylococcus aureus and Eschericia coli .," J. Biomed., vol. 1, no. 2, pp. 1-10, 2012.

[25] X. Yang, X. Zhang, S. P. Yang, and W. Q. Liu, "Evaluation of the antibacterial activity of patchouli oil," Iran. J. Pharm. Res., vol. 12, no. 3, pp. 307-316, 2013, doi: 10.22037/ijpr.2013.1320.

[26] Y. Mulyani, E. Bachtiar, and M. U. K. Agung, "The role of secondary metabolites of mangrove plants against bacterial infections Aeromonas hydrophila on fish Mas ( Cyprinus carpio L ). Peranan senyawa metabolit sekunder tumbuhan mangrove terhadap infeksi bakteri Aeromonas hy-drophila pada ikan mas (Cy," Aquat. J., vol. 4, no. 1, pp. $1-9,2013$.

[27] B. Burhanuddin, A. Saru, A. Rantetondok, and E. N. Zainuddin, "Antibacterial activity Rhizophora stylosa and Avicennia marina of mangrove fruit extraction on vibriosis of mangrove crab larvae (Scylla Serrata Forsskal)," Int. J. Environ. Agric. Biotechnol., vol. 4, no. 4, pp. 1242-1248, 2019, doi: 10.22161/ijeab.4452.

[28] I. Ciptaningrum and A. . Reyhan, "Effect antimicrobacterial Rhizophora apiculta for inhibits growth of bacteria. Efek antimikroba Rhizophora apiculata untuk menghambat pertumbuhan bakteri.," Pharm. J., vol. 8, no. 2, pp. 75-82, 2019.

[29] G. Sahoo, N. S. S. Mulla, Z. A. Ansari, and C. Mohandass, "Antibacterial activity of mangrove leaf extracts against human pathogens," Indian J. Pharm. Sci., vol. 74, no. 4, pp. 348-351, 2012, doi: 10.4103/0250-474X.107068.

[30] Z. A. Alhaddad, W. A. Tanod, and D. Wahyudi, "Antibacterial bioactivity of mangrove leaf extracts Avicennia sp. Bioaktivitas antibakteri dari ekstrak daun mangrove Avicennia sp.," Mar. J., vol. 12, no. 1, pp. 12-22, 2019, doi: 10.21107/jk.v12i1.4752. 